\title{
Influence of non-genetic factors on growth traits of Horro (Zebu) and their crosses with Holstein Friesian and Jersey cattle
}

\author{
Habtamu Abera ${ }^{1 *}$, Solomon Abegaz $^{2}$ and Yoseph Mekasha ${ }^{3}$ \\ ${ }^{1}$ Bako Agricultural Research Center, P. O. Box 03 Bako, Ethiopia. \\ ${ }^{2}$ Institute of Biodiversity, Addis Ababa, Ethiopia. \\ ${ }^{3}$ Haramaya University P. O. Box 138 Dire Dewa, Ethiopia.
}

\begin{abstract}
Accepted 21 December, 2011
The present study was carried out to determine non-genetics effects on the growth performance (birth, weaning, one year weight and weight gains) of Horro cattle and their crosses (Friesian-Horro (FH) and Jersey-Horro (JH)) at Bako Agricultural Research center. The data used in the study included weight records of animals born between 1980 and 2008. Least squares means were analyzed using General Linear Model (GLM) of Statistical Analyses System (SAS). Apart from Breed effects, sex, year of birth and parity were the main non genetic effects that influenced birth weight (BW), weaning weight (WW), one year weight (YW), pre-weaning average daily gain (DG) and post-weaning average daily gain (PDG). The overall mean of birth, weaning and one year weight and pre-weaning and post-weaning average daily gains of Horro and their crosses were $19.6 \pm 0.16 \mathrm{~kg}, 43.8 \pm 8.5 \mathrm{~kg}$ and $84.8 \pm 21 \mathrm{~kg}, 407.4 \pm 20.6 \mathrm{~g}$ and $263.7 \pm 54.3 \mathrm{~g}$, respectively. The least squares means birth weight, weaning weight and one year were: $18.34 \pm 0.14 \mathrm{~kg}, 39.8 \pm 0.39 \mathrm{~kg}$ and $70.5 \pm 1.14 \mathrm{~kg}$ for Horro, $22.13 \pm 0.14 \mathrm{~kg}, 47.5 \pm 0.38 \mathrm{~kg}$ and $94.7 \pm 1.14 \mathrm{~kg}$ for Friesian-Horro and $19.1 \pm 0.19 \mathrm{~kg}, 42.9 \pm 0.5 \mathrm{and} \mathrm{kg}, 85.5 \pm 1.5 \mathrm{~kg}$ for Jersey-Horro breeds, respectively. From the results suggests that birth weight of the calves doesn't affect the weaning weight and the subsequence growth performance. This could point to an opportunity for much improved weaning and one year weight by improving the management practices of calves. The higher growth performance observed for the crossbred calves in comparison with the purebred Horro (Bos indicus) cattle.
\end{abstract}

Key words: Crosses, fixed, growth, Horro, non genetic, traits.

\section{INTRODUCTION}

Weight at birth is one of the first characteristics of an animal that can be easily measured and had been important in predicting weaning weight and rate of gain in growth (Mohamed, 2004). Genetic improvements through selection for growth traits are less desirable because the expected rate of genetic gain can be very low while crossbreeding is an alternative genetic improvement approach to improve traits with such low heritability (Hailu

${ }^{*}$ Corresponding author. E-mail: hmaassee@gmail.com. and Tadele, 2004). The growth traits of calves under tropical condition are affected by the genotype of the calf, season of birth, age of the dam and feeding and management condition. Holland and Odde (1992) reported that the variations of birth weight are the results of different growth rates during the prenatal development. Several works had reported that growth performance can be influenced by year and season of birth, age, lactation status (parity) and fertility of the dam, breed and sex of the calf (Mohamed, 2004). Birth weights of calves are affected by a variety of genetic and environmental factors (Habtamu et al., 2008). The observed average birth weight 
for these Horro and Horro-Jersey are smaller than the values reported for Arsi $x$ Holstein-Friesian calves in Arsi (Kiwuwa et al., 1983), Boran $x$ Friesian calves at Abernosa (Ababu et al., 2006) and Fogera x Friesian calves at Metekel (Addisu, 1999; Ababu, 2002). Horro crossbred calves were heavier at birth than pure Horro calves. Birth weight differences can also happen due to the differences in the pre-partum management of the cows, as the health and vigor of calves at birth depends on the nutrition of the cow during the last 60 days before freshening. During this period, approximately $70 \%$ of the birth weights of the calf develop and the cow must store nutrients for early lactation when milk production exceeds the cow's capacity for feed consumption (Kellems and Church, 1998). Therefore, the objective of present study is to determine non-genetics effect on growth traits of Horro and their crosses with Holstein Friesian and Jersey calves.

\section{MATERIALS AND METHODS}

\section{Location}

The data used in this study was generated from Horro cattle and their crosses kept at Bako agricultural research centre. The centre is located at about $250 \mathrm{~km}$ West of Addis Ababa at an altitude of $1650 \mathrm{~m}$ above sea level. The centre lies at about $09^{\circ} 6^{\prime} \mathrm{N}$ and $37^{\circ} 09^{\prime} \mathrm{E}$. The area has a hot and subhumid climate and receives a mean annual rainfall of about $1220 \mathrm{~mm}$, of which more than $80 \%$ falls in the months of May to September. Mean monthly minimum and maximum temperatures are about 14 and $28^{\circ} \mathrm{C}$, respectively, with an average monthly temperature of $21^{\circ} \mathrm{C}$. The daily mean minimum and maximum temperatures are 9.4 and $31.3^{\circ} \mathrm{C}$, respectively.

\section{Breeding system}

At Bako Agricultural Research Center, heifers bred at least two years of age when they attained a body weight of $200 \mathrm{~kg}$. Heat detection was done visually every day from $06: 00$ to $08: 00 \mathrm{~h}$ in the morning and from 17:00 to $18: 00 \mathrm{~h}$ in the afternoon by trained inseminator and during the grazing time by the herdsmen. Cows and heifers observed in heat were bred either naturally (local or crossbred bull) or inseminated with frozen semen (Friesian and Jersey) purchased from Kality National Artificial Insemination center within $24 \mathrm{~h}$ after heat.

\section{Management of calves at Bako agricultural research center}

Calves were separated from their dams at birth, weighed and fed colostrums from a bucket for the first five days of life. A total of 227 $L$ of milk was fed to each calf and a concentrate mix (49.5\% ground maize, $49.5 \%$ Noug seed cake and $1 \%$ Salt) were offered until weaning (three months), then after both calves (male and female) were kept indoors (day and night) until six months of age in individual pens except for about two hours of exercise in a nearby paddock every day. After six months of age, weaned calves were maintained on natural pastures for approximately eight hours a day and supplemented with silage or hay ad libitum during the night and were kept as a group (male and female separately), where concentrated supplemented heifer calves are only available. Vegetation cover of the area is woodland and open wood grassland types. The dominant grass species include hyperheniya (Hyperhenia anamesa) and sporobolus (Sporobolus praminidals) grass and the legumes include Neonotonia (Neonotonia wights).

\section{Data collection and preparation}

The data used for this study include weight records of animals born between 1980 and 2008. Data were extracted from various growth records (birth, weaning and one year weight) of Horro and its crossbred animals at Bako agricultural research center. The data entered were checked for entry and extraction errors using the univariate procedure of SAS (1999). A total of 2359 calves records were used in the analysis.

\section{Traits considered}

Birth weight (BW; weight taken within $24 \mathrm{~h}$ of birth); Weaning weight (WW; weight recorded at three months of age); Pre-weaning average daily weight gain (DG; gains from birth to three months); Post- weaning average daily weight gain (PDG; gain from three months to one year); and one year weight (YW; weight recorded at 12 month age). Daily gains were calculated by dividing the difference between the initial and final weight with the number of days.

\section{Statistical analysis for estimation of non-genetic effects}

In order to determine the effects of non-genetic factors such as breed, year of birth, parity and sex, the analysis were performed using the general linear models. Procedure of SAS (SAS, 1999). Duncan test is utilized for comparison of least square mean. Fixed effects for all growth traits include sex, year of birth, breed and parity while ages at weaning and one year were fitted as linear covariates in the analysis of weaning weight, pre-weaning average daily gains and one year weight and post-weaning average daily gain. In addition, for birth weights Julian birth day (JBD) (Date of birth of the calves as counted from 1st of January) was fitted as a linear covariate. This is due to the fact that seasonal categories can put calves born within a few days difference may be fall into different seasons, while JBD can avoid this problem (Solomon, 2002). Interaction effects of fixed factors (year by parity, year by sex, year by breed, parity by sex, parity by breed and sex by breed) were tested and had no significant effect on all the traits studied. The following models were fitted for BW, WW DG, PDG and YW:

$Y_{i j e n o}=\mu+G_{i}+Y_{j}++S_{e}+P_{n}+e_{i j m e n l o}$

Where: $Y_{\text {ijeno }}=n^{\text {th }}$ records of the $i^{\text {th }}$ breeds, $j^{\text {th }}$ year, $e^{\text {th }}$ sex, nth parity and $\mu=$ overall mean. $G_{i}=$ fixed effect of the $i^{\text {th }}$ breed. $Y_{j}=$ fixed effect of $j^{\text {th }}$ year of birth. $S_{e}=$ fixed effect of $e^{\text {th }}$ sex of calf. $P_{n=}$ fixed effect of $n^{\text {th }}$ parity. $e_{\text {ijeno }}=$ residual error.

\section{RESULTS AND DISCUSSION}

The summarized results from the analysis of variance for birth, weaning, one year weight, pre-weaning and post- 
Table 1. Analysis of variance for birth, weaning, one year weight and pre-weaning and post-weaning average daily gains.

\begin{tabular}{|c|c|c|c|c|c|c|}
\hline Source & $\mathrm{DF}$ & BW & WW & YW & DG & PDG \\
\hline Breed & 2 & $6059.44^{\star *}$ & $18477.9^{* *}$ & $140158.5^{\star *}$ & $627216.0^{* *}$ & $509699.1^{* *}$ \\
\hline Parity & 6 & $842.8^{*}$ & $1118.4^{*}$ & $4201.0^{*}$ & $198744.2^{*}$ & $12944.0^{*}$ \\
\hline Sex & 1 & $590.6^{\star *}$ & $466.6^{*}$ & $27174.6^{\star \star}$ & $269074.2^{\star *}$ & $179150.6^{* *}$ \\
\hline Year & 28 & $2694.3^{\star \star}$ & $15233.7^{\star \star}$ & $137621.8^{\star *}$ & $1535583.9^{* *}$ & $1167330.5^{\star \star}$ \\
\hline Age & 1 & & $5076.7^{\star \star}$ & $1950.7^{*}$ & $322621.1^{* *}$ & $21953.5^{\star *}$ \\
\hline Model & 38 & $11830.0^{* *}$ & $51715.4^{\star \star}$ & $372831.7^{\star *}$ & $3601706.7^{\star *}$ & $2050086.4^{* *}$ \\
\hline $\mathrm{JBD}$ & & $52.75^{*}$ & - & - & & \\
\hline$R^{2} \%$ & & 29 & 28 & 36 & 16 & 33 \\
\hline CV \% & & 17.9 & 19.4 & 25.8 & 34 & 46 \\
\hline
\end{tabular}

${ }^{*}, \mathrm{P}<0.05 ;{ }^{* *}, \mathrm{p}<0.01$.

weaning average daily gains, are presented in Table 1. All the factors in the model contributed significantly in explaining the variation in the growth traits. The coefficients of variation increased from birth weight to one year weight. The increase can be partly explained by reduction in number of observations as the age increase from birth to one year because of death loss and culling of some calves. Additionally it may be due to the differences between environments in particular age, management practices and inconsistencies in feed availability. The coefficients of variation from the current study are in agreement with those of Demeke et al. (2003b) who have reported 8.7 to $27.9 \%$ for growth traits of crossbred cattle.

The overall mean birth, weaning and one year weight and pre-weaning and post-weaning average daily gains of Horro and their crosses were $19.6 \pm 0.16 \mathrm{~kg}, 43.8 \pm 8.5$ $\mathrm{kg}$ and $84.8 \pm 21 \mathrm{~kg}, 407.4 \pm 20.6 \mathrm{~g}$ and $263.7 \pm 54.3 \mathrm{~g}$, respectively (Table 2). The mean values of growth performance in this study were lower than values reported for other Ethiopian cattle breeds (Addisu, 1999; Ababu, 2002; Demeke et al., 2003b, 2004b; Hailu, 2003; Addisu and Hegede, 2003; Aynalem, 2006). The low mean growth traits obtained in this study could be attributed to the calf rearing systems and environmental conditions of the production area. Similar findings were reported on growth traits of Horro by Mulugeta (2003), Demeke et al. (2003b, 2004b), Jiregna et al. (2006) and Habtamu et al. (2008). The results also correspond with Demeke et al. (2003a) reported that the lowest weaning weight of $88 \mathrm{~kg}$ due to bucket feeding. The one year weight observed in this study was lower than results obtained by Haile-Mariam and Kassa-Mersha (1995) which is due to artificial rearing of the calves where maternal effects on calf growth tended to die out earlier than naturally reared. The variation in the birth weight of calves over the years might be associated with the prepartum management of the cows and variation in management during the years. And also be related to nutritional and climatic conditions particularly rainfall patterns. Fluctuations in weaning and one year weights performance across the years depicted the sensitivity of calves to postnatal stress. Growth performance of calves could have been reduced due to exposure to prolonged nutritional stress. The coefficient of variation has shown slight increase with increases in age. This may indicate increased role of the environment in causing the variation.

Body weight at birth was significantly $(p<0.05)$ affected by parity, where calves born from first parity being lighter at birth than those born from adult cows (Table 2). The difference was, however, only significant between first, second and third parity born calves. Similar works reported by Addisu and Hegede (2003) showed that calves born from first calver were significantly lighter than those calves born from second to fifth calvers of cows. Demeke et al. (2003b) reported that dam parity effects were significant sources of variation in birth weight, preweaning average daily gain, weaning weight and one year weight. This variation could be attributed to a good maternal environment provided by mature cows to the newly developing fetus, competition for nutrients between fetal development and maternal growth which is high in younger dams than older ones. Heavier weaning weight are expected in calves from older dams due to well developed mammary tissue relative to younger dams thus better maternal environment in terms of milk for the suckling calf (Wasike, 2006). This fact was not observed in current results due to the withdrawal of maternal environment at early ages. In agreement to the present finding, significant effects of parity were also observed in the performance characterization study of the Boran and Sahiwal cattle (Trail and Gregory, 1981). The lowest weaning and one year weights were recorded for calves from seventh parity and highest weaning and one year weight for calves from second and third parity.

Birth weight of the calves significantly $(p<0.05)$ 
Table 2. Least square means ( \pm s.e) of birth, weaning, and one year weight and pre-weaning and post-weaning average daily gains for breeds, parity, sex, and regression coefficient of Julian birth date on birth weight, and age of weighing on weight and daily gain.

\begin{tabular}{llllll|ll|ll|ll}
\hline Effect & Level & $\mathbf{N}$ & $\mathbf{B W}(\mathbf{k g})$ & $\mathbf{N}$ & $\mathbf{W W}(\mathbf{k g})$ & $\mathbf{N}$ & $\mathbf{Y W}(\mathbf{k g})$ & $\mathbf{N}$ & $\mathbf{D G} \mathbf{( g m})$ & $\mathbf{N}$ & PDG (gm) \\
\hline Parity & 1 & 709 & $18.8 \pm 0.15 \mathrm{bc}$ & 577 & $43.6 \pm 0.39$ & 451 & $83.6 \pm 1.2$ & 577 & $309.8 \pm 4.7$ & 451 & $112.5 \pm 2.8$ \\
& 2 & 320 & $20.13 \pm 0.16 \mathrm{a}$ & 441 & $44.07 \pm 0.43$ & 352 & $85.5 \pm 1.3$ & 441 & $299.4 \pm 5.3$ & 352 & $116.7 \pm 3.1$ \\
& 3 & 397 & $20.3 \pm 0.18 \mathrm{a}$ & 318 & $45.3 \pm 0.50$ & 236 & $87.2 \pm 1.5$ & 318 & $312.0 \pm 6.02$ & 236 & $118.1 \pm 3.6$ \\
& 4 & 284 & $20.3 \pm 0.22 \mathrm{a}$ & 205 & $43.5 \pm 0.63$ & 161 & $84.0 \pm 1.8$ & 205 & $289.3 \pm 7.5$ & 161 & $113.9 \pm 4.5$ \\
& 5 & 198 & $19.8 \pm 0.26 \mathrm{ab}$ & 151 & $42.9 \pm 0.73$ & 116 & $82.3 \pm 2.2$ & 151 & $285.6 \pm 8.8$ & 116 & $108.2 \pm 5.3$ \\
& 6 & 130 & $19.8 \pm 0.33 \mathrm{ab}$ & 93 & $42.8 \pm 0.93$ & 66 & $81.9 \pm 2.8$ & 93 & $287.3 \pm 11.1$ & 66 & $111.5 \pm 6.8$ \\
& $\geq 7$ & 121 & $19.9 \pm 0.35 \mathrm{ab}$ & 90 & $41.7 \pm 0.97$ & 65 & $80.2 \pm 2.9$ & 90 & $271.7 \pm 11.7$ & 65 & $107.6 \pm 7.2$ \\
Sex & Male & 1224 & $20.4 \pm 0.13 \mathrm{a}$ & 931 & $42.9 \pm 0.4 \mathrm{a}$ & 674 & $79.1 \pm 1.0 \mathrm{~b}$ & 931 & $281.2 \pm 4.3 \mathrm{~b}$ & 674 & $101.3 \pm 3 \mathrm{~b}$ \\
& Female & 1135 & $19.4 \pm 0.13 \mathrm{a}$ & 944 & $43.9 \pm 0.4 \mathrm{a}$ & 775 & $88.0 \pm 1.0 \mathrm{a}$ & 944 & $305.8 \pm 4.3 \mathrm{a}$ & 775 & $124.0 \pm 3 \mathrm{a}$ \\
Breeds & HH & 1001 & $18.34 \pm 0.14^{\mathrm{c}}$ & 726 & $39.8 \pm 0.39^{\mathrm{c}}$ & 600 & $70.5 \pm 1.14^{\mathrm{c}}$ & 726 & $270.8 \pm 4.7^{\mathrm{c}}$ & 600 & $86.3 \pm 3^{\mathrm{c}}$ \\
& HF & 961 & $22.13 \pm 0.14^{\mathrm{a}}$ & 812 & $47.5 \pm 0.38^{\mathrm{a}}$ & 597 & $94.7 \pm 1.14^{\mathrm{a}}$ & 812 & $314.7 \pm 4.5^{\mathrm{a}}$ & 597 & $132 \pm 2.8^{\mathrm{a}}$ \\
& HJ & 397 & $19.1 \pm 0.19^{\mathrm{b}}$ & 337 & $42.9 \pm 0.52^{\mathrm{b}}$ & 252 & $85.5 \pm 1.5^{\mathrm{b}}$ & 337 & $295.1 \pm 6.3^{\mathrm{b}}$ & 252 & $119.7 \pm 4^{\mathrm{b}}$ \\
JBD & & & $0.0014 \pm 0.0007$ & & & & & & & & \\
Age & & & & & $0.18 \pm 0.21$ & & $0.13 \pm 0.063$ & & $-1.43 \pm 0.25$ & & $-0.43 \pm 0.2$ \\
\hline
\end{tabular}

${ }^{a-c}$ Means or least square means in the same row and with different superscripts are significantly different; BW=Birth weight; WW=Weaning weight; $D G=$ pre-weaning average daily gain; $P D G=$ post-weaning average daily gain; $Y W=$ one year weight; $N=$ Number of observations; Age = Age (days) at weaning; JBD = Julian birth day.

influenced by sex, where male calves were heavier than females at birth. However, female calves were superior $(p<0.05)$ at weaning and one year and also had faster growth rate than male calves. Pre-weaning and postweaning daily gains for female calves were higher than males (Table 2). These findings were consistent with earlier reports on Horro cattle (Mulugeta, 2003; Jiregna et al., 2006; Habtamu et al., 2008) and on Fogera cattle and their crosses (Addisu and Heged, 2003). Males were $1 \mathrm{~kg}$ heavier than females at birth; however, females were 1 $\mathrm{kg}$ heavier than males at weaning and $8.9 \mathrm{~kg}$ heavier at one-year weight. The results is not in agreement with Aynalem (2006) who reported that males were $1.5 \mathrm{~kg}$ heavier at weaning, $7.5 \mathrm{~kg}$ heavier at one year, $8.5 \mathrm{~kg}$ heavier at eighteen months and $8.8 \mathrm{~kg}$ heavier at two years of age for Boran cattle. Also the present result is not in agreement with other reports (Banjaw and HailMariam, 1994; Rege et al., 1994; Demeke et al., 2003b; Wasike, 2006). The possible reason for higher weight in females than in males at weaning and thereafter was that especial management was given to females to improve the growth rate of replacement heifers to enable them reach puberty and start production life earlier. This situation indicated that special management assigned to calves could result in improvement of their life weights production and reproduction. Birth, weaning and one year weight and pre-weaning and post-weaning average daily gains of calves were significantly $(P<0.05)$ affected by breeds (Table 2). Horro calves had lower growth performance than the Friesian and Jersey crosses. This has also been confirmed previously (Mulugeta, 2003; Jiregna et al., 2006; Habtamu et al., 2008) on Horro cattle and their crosses with Frisian and Jersey and for other indigenous cattle breeds (Addisu, 1999; Ababu, 2002; Demeke et al., 2003b, 2004b; Hailu, 2003; Addisu and Hegede, 2003; Aynalem, 2006). Increase in birth weight with increasing level of exotic blood had been reported by Ahunu et al. (1993). Aynalem (2006) also reported that calves of Ethiopian Boran breed were consistently lighter than all the Ethiopian Boran-Friesian crosses at birth, weaning, six months, one year, eighteen months and two years of age. The reason is that different genotypes are not expected to perform similarly under all environments mainly due to genotype-environmental interactions (Bourdon, 2000). This implied that growth varies with the breed and environment. The superiority of the crossbreds over the Horro calves indicated the effect of heterosis as result of crossing with the Jersey and Friesian breed, since both groups bucket fed (artificially reared). The weaning and one year weights that were observed from this study are generally low compared with Bos taurus $\mathrm{x}$ $B o s$ indicus crossbred animals raised through suckling in beef production systems in the tropics (Banjaw and HailMariam, 1994). But these weights are also not uncommon for crossbred dairy animals reared artificially under low input systems in the tropics (Kebede and Galal, 1982; Thorpe et al., 1993; Rege et al., 1994; Hirooka and Bhuiyan, 1995; Demeke et al., 2003b). Age at weaning and one year were significantly influence weaning, pre-weaning, one year and post-weaning 
weights.

\section{CONCLUSIONS AND RECOMMENDATIONS}

The average birth, weaning and one year weight of Horro cattle and their crosses are relatively low in the present study as compared to other results. From previous studies on similar genotypes there is evidence of environmental influence on the growth performance. The significant effects of parity, sex, year and period of the year birth has taken place (Julian birth day) indicates the importance of considering these factors in the management of Horro cattle and their crosses with Friesian and Jersey for improved growth performance. Ofparticular importance are effect of year of birth which could be related to better nutritional and climatic environments mainly due to the difference in rainfall patterns and the direct effect on the availability and quality of nutrients. The significant regression of age at weight on weaning and yearling weight implies that adjustments for the number of days before or after the standard age need to be made on respective weights. Higher growth performance was observed for the crossbred calves in comparison with the purebred Horro cattle in this study. The crossing of Horro with the breeds involved in this study would have beneficial effect on growth. Based on the findings of this result Friesian crosses should be recommended for early growth rate under Bako and similar environmental conditions.

\section{ACKNOWLEDGMENTS}

Our sincere appreciation and gratitude goes to Oromia Agricultural Research Institute for the opportunity given to the first author to pursue postgraduate studies, and Bako Agricultural Research Center for providing the highly valuable research data used in the study.

\section{REFERENCES}

Ababu D (2002). Evaluation of Performance of Boran Cows in the Production of Crossbreed Dairy Heifers at Abernosa Ranch, Ethiopia. An MSc Thesis presented to School of Graduate studies of Alemaya University. pp. 55-65.

Ababu D, Workneh A, Hedge PB, Zerihun T (2006). Performance of the Abernosa Ranch in the Production of Ethiopian Boran X Holstein Crossbreed Dairy Heifers in Ethiopia. Eth. J. Anim. Prod. 6(1):33-53.

Addisu B, Hegede PB (2003). Reproductive and growth performance of Fogera cattle and their F1Friesian crosses at Metekel ranch, Ethiopia.. Challenges and Opportunities of Livestock Marketing in Ethiopia. Proceedings of the 10th Annual Conference of the Ethiopian Society of Animal Production (ESAP) held in Addis Ababa, Ethiopia, August 22-24, 2002. ESAP, Addis Ababa. p. 407

Addisu B (1999). Evaluation of reproductive and growth performance of Fogera cattle and their F1 Friesian cross at Metekel Ranch. An MSc
Thesis presented to School of Graduate studies of Alemaya University. p. 55

Aynalem H (2006). Genetic and Economic Analysis of Ethiopian Boran Cattle and their Crosses with Holstein Friesian in Central Ethiopia. A Ph.D. Thesis division of dairy cattle breeding National dairy research institute, Karnal-132001 (Haryana), India. pp. 65-146.

Banjaw K, Haile-Mariam M (1994). Productivity of Boran cattle and their Friesian crosses at Abernossa ranch, rift valley of Ethiopia. II. Growth performance. Trop. Anim. HIth. Prod. 26:49-57.

Bourdon RM (2000). Understanding animal breeding. 2nded. Prentice Hall. New Jersey. Burfening. p. 102.

Demeke S, Neser FWC, Schoeman SJ (2003a). Variance components and genetic parameters for early growth traits in a mixed population of purebred Bos indicus and crossbred cattle. Livest. Prod. Sci. 84:1 11.

Demeke S, Neser FWC, Schoeman SJ (2003b). Early growth performance of Bos Taurus $x$ Bos indicus cattle crosses in Ethiopia: Evaluation of different crossbreeding models. J. Anim. Breed. Genet. 120:39-50.

Demeke S, Neser FWC, Schoeman SJ (2004b). Estimates of genetic parameters for Boran, Friesian and crosses of Friesian and Jersey with the Boran cattle in the tropical highlands of Ethiopia: milk production traits and cow weight. J. Anim. Breed. Genet. 121:163.

Habtamu A, Mulugeta K, Ulfina G, Jiregna D, Tsegaye C (2008). The effect of different weaning age on growth performance of calves under full suckling system at Horro Guduru Cattle Breeding and Improvement Ranch.Pastoral livestock System: Pp.115 Opportunities and challenges as a Livelihood Strategy. Proceeding of the $15^{\text {th }}$ Annual Conference of the Ethiopia Society of Animal Production (ESAP) held in Addis Ababa, Ethiopia, Octeber 4-6, 2007.

Hailu D, Tadele M (2004). Influence of Dam Genotype, Age of Dam and Parity on Age at FirstCalving, Calving Interval and Birth Weight in Indigenous and Crossbred Cattle at Adami Tulu.p.227-232.Farm Animal Biodiversity in Ethiopia: Status and Prospects. Proceedings of the 11th annual conference of the Ethiopian Society of Animal Production (ESAP) held in Addis Ababa, Ethiopia, August 28-30, 2003.

Hailu D (2003). Effects of sire and dam breed genotypes on preweaning traits of calves in indigenous (Boran and Barka) and indigenous $X$ Bos Taurus crossbred cattle. pp. 407. Challenges and Opportunities of Livestock Marketing in Ethiopia. Proceeding of the 10th Annual conference of the Ethiopian Society of Animal Production (ESAP) held in Addis Ababa, Ethiopia, August 22-24, 2002. ESAP, Addis Ababa.

Hirooka H, Bhuttyan AKFH (1995). Additive and heterosis effects on milk yield and birth weight from crossbreeding experiments between Holestien Friesian and the local breed. Am. J. Anim. Sci. 8:295-301.

Holland MD, Odde KG (1992). Factors affecting calf birth weight. A review. Theriogenology (USA) 38(5):769-798.

Jiregna D, Ulfina G, Mulugeta K, Adisu Y (2006). Growth Performances and Mortality rate of Horro Calves under different weaning system. $p$. 151. The Role of Agricultural Universities/Colleges in Transforming Animal Agriculture in Education, Research and Development in Ethiopia: Challenges and Opportunities. The Proceedings of the 13th annual conference of the Ethiopian Society of Animal Production (ESAP) held in Addis Ababa, Ethiopia, August 25-27, 2005.

Kebede B, Galal ESE (1982). A study of body weight from birth to one year of age in European-zebu crossbred cattle in Ethiopia. Anim. Prod. 34:85-93.

Kellems O, Church DC (1998). Livestock feeds and feeding $4^{\text {th }}$ ed. Prentice Hall, Upper Saddle River, New Jersey 07458. p. 573.

Kiwuwa GH, Trail JCM, Kurtu MY, Worku G, Anderson FM, Durkin J (1983).Crossbred dairy cattle productivity in Arsi region, Ethiopia.ILCA Research Report No.11.ARDU and ILCA, Addis Ababa, Ethiopia.

Mohamed A (2004). Estimates of genetic parameters of birth weight, age at first calving and milk production traits in Holstein Friesian dairy herds kept in three state farms. An MSc Thesis presented to School 
of Graduate studies of Alemaya University. p. 89.

Mulugeta K (2003). An Evaluation of Reproductive performance of Horro cattle in Ethiopia. 2003. Ph.D. Thesis. Free State University, Texas, South Africa. p. 48.

Rege JEO, Aboagye GS, Akah S, Ahunu BK (1994) Crossbreeding Jersey with Ghana Shorthorn and Sokoto Gudali cattle in a tropical environment: Additive and Heterotic effects for milk production, reproduction and calf growth traits. Anim. Prod. 59: 21-29.

SAS (Statistical Analyses System) (1999). SAS User's Guide. Cary, North Carolina, USA, SAS Institute Inc., NY, Cary.

Solomon A (2002). Genetic evaluation of production, reproduction and survival in a flock of Ethiopian Horro sheep. Ph .D. Thesis, University of Free State Bloemfontein, South Africa. pp. 10-47.
Trail JCM, Gregory KE (1981). Characterisation of the Boran and Sahiwal breeds of cattle for economic characters. J. Ani. Sci. 52:1286-1293.

Wasike CB (2006). Genetic evaluation of growth and reproductive performance of Kenya Boran Cattle. A MSc. Thesis, Egerton University, Njoro, Kenya. pp. 65-77. 